\title{
Culture in the Rise of Tiger Economies: Scottish Expatriates in Dublin and the 'Creative Class' Thesis
}

\author{
MARK BOYLE
}

\begin{abstract}
This article evaluates the contributions which Richard Florida's seminal 'creative class' thesis might make to ongoing efforts to re-inscribe 'culture' back into political economy explanations of the rise of Tiger economies. It reflects upon the value of reconsidering both the role of skilled migrants in Tiger states and the factors which attract skilled migrants to these economies in the first instance. Based upon analyses of a series of focus groups conducted with Scottish expatriates currently working in Dublin, the article specifically attempts to gauge how far the creative class thesis can be stretched to account for the locational preferences of talented migrants. Whilst Florida's work undoubtedly sheds light on aspects of expatriate existence which might not otherwise have been obvious, its ability to account for the relationships which have existed between technology, talent and tolerance in the Celtic Tiger must be questioned. Moreover, if political economy and Floridian readings are to do more than simply inform one another, there will be a need to establish more clearly the complex ways in which developmental states intersect with skill flows and cosmopolitan cultural agendas.
\end{abstract}

\section{Culture in the rise of Tiger economies}

In searching for economies which merit the noun 'Tiger', most commentators begin with the Pacific Asian region and with good cause. This region has been witness to three waves of world class economic growth, with Japan pioneering the first wave, the four 'dragon economies' of South Korea, Taiwan, Hong Kong and Singapore taking up the mantle in the second, and finally, the three South East Asian 'cubs' of Malaysia, Thailand and Indonesia rising to announce the third wave (Pang, 1994). Subsequently, the economic success enjoyed by Vietnam, Myanmar and China has been taken to constitute a fourth wave. Beyond Pacific Asia, nevertheless, lie a number of other contenders. Whilst Brazil, Mexico and India have sought to claim Tigerhood for some time, more recently countries as diverse as Ireland and Israel, and even Chile, Mauritius and Botswana have attracted the label (O'Hearn, 2000; O'Riain, 2000; 2004).

As the membership base has expanded, debate has increasingly focused upon the extent to which it remains possible to speak of a single Tiger model of growth. The dragon economies of course are taken to be paradigm examples of the virtues of developmental states and their brand of state technocracy and command capitalism (Evans, 1995). According to some commentators, however, globalization has sounded 
the death knell for developmental accumulation strategies. The Tigers emerging today are not being steered by an interventionist state but instead are been lubricated by a neoliberal agenda which is seeking growth by rolling back regulation and pinning down footloose transnational capital (O’Hearn, 1998; 2000). Occupying more central ground, other critics have cautioned against the all too easy rejection of the concept of the developmental state and have sought to extend the notion by contrasting the 'bureaucratic developmental states' of Pacific Asia with a new breed of 'flexible developmental state' or 'developmental networked state' (O'Riain, 2000; 2004).

Insofar as they are seeking to account for truly formidable economic growth rates, it is perhaps unsurprising that the various explanatory frameworks proposed to date have drawn upon more muscular political economy perspectives. Accompanying political economy debates on the various pathways that have led to Tigerhood, nevertheless, and inspired in part by the cultural turn in the new economic geography, some recent work has also revealed a refreshing interest in the role of 'culture' in the rise of Tiger economies. In literature on the Pacific Asian Tigers alone, for instance, it is possible to identify at least four ways in which the concept of culture has been mobilized.

Firstly, new narratives of the nation and new supra-national 'imagined communities' have been mobilized to boost national self confidence and legitimate socially divisive economic development programmes (Wee, 2001; Chang and Lim, 2004; Sparke et al., 2004). Secondly, local social networks, technology clusters and knowledge communities have combined to create an atmosphere of entrepreneurship and innovation and served as a catalyst for the rise of post-Fordist industrial districts and networked learning regions (O'Riain, 2000; 2004; Beaverstock, 2002; Low, 2005). Thirdly, 'culturalization' of the economy has enhanced not only the contribution of the formal cultural industries to national income but also the significance of companies reliant upon creative product design and trading symbolic goods in market places driven by consumption tastes and lifestyle dispositions (Chang, 2000a; 2000b). Finally, cosmopolitan and multicultural agendas have been promoted in order to attract investment and skilled international migrants in key sectors of the economy (Li et al., 1998; Yeoh and Chang, 2001; Yeoh, 2005).

In spite of recent progress, there remains a need to interrogate more systematically and forcefully the status of culture in the emergence of Tiger economies. In searching for an explanatory framework which affords culture a more central role in urban and regional growth, this article turns attention to Richard Florida's recent 'creative class' thesis (Florida, 2002; 2005a; 2005b). According to Florida, the successful cities and regions in future will be the ones most endowed with the 3Ts: technology, talent and tolerance. Whilst Florida claims that all three elements are equally important, it is clear that the originality of his thesis rests upon the priority he ascribes to each relative to traditional orthodoxy. According to Florida, pools of creative talent are at least as important as stocks of technology in driving urban and regional development, and the cultural atmosphere of a place is at least as important as its technological labour markets in drawing creative talent to cities and regions.

If Florida is to convince political economy frameworks to open up even more to culture, he needs to be able to provoke a reconsideration of the status of skilled personnel and skilled migrants in the rise of Tiger economies. Within political economy literature skilled international migration has been viewed as a response to the uneven insertion of national economies into the new international division of labour. Skilled migrants have been channelled into Tiger states from major business centres in Europe, North America and Japan; initially to establish low-value-added assembly platforms, then to promote a movement towards high-value-added export-oriented production, and more recently, as some Tigers have aspired to world city status, to enhance global command and control capability in corporate headquarters and global producer services companies (Pang, 1994; Findlay et al., 1996; 1998; Hui, 1997; Yeoh and Chang, 2001; Beaverstock, 2002; Low, 2002; 2005; Abella, 2004).

But has this literature inadequately diagnosed the location of mobile talent in the causal sequence? According to Florida, the causal chain 'tolerance attracts talent which 
stimulates technological innovation and creates growth' is just as persuasive as political economy assumptions which hold that 'technology creates jobs, jobs attract talent, and talent creates tolerance'. Tiger economies are so successful because they have been blessed with the cultural qualities necessary to attract members of the creative class and once in situ this class has driven growth. This argument gives rise to the question: does skilled labour settle in Tiger states for reasons other than mere economic opportunity, and are these migrants as much a cause of growth as a consequence?

In a critical review of the 'cultural turn' in the new economic geography, Gregson et al. (2001; see also Shields, 1999; Simonsen, 1999; 2001; Kong, 2000; Pratt, 2004; Miles and Paddison, 2005), observe the ways in which the concepts of 'political economy' and 'culture' have been variously and poorly defined within the urban and regional studies literature in particular (see also Shields, 1999; Simonsen, 1999; 2001; Kong, 2000; Pratt, 2004; Miles and Paddison, 2005). This in turn has led cultural perspectives to be either cannibalized by political economy approaches or to proceed with only minimal recognition of the power of economic and political forces. As a consequence Gregson et al. (2001) call for oppositional thinking to be resolved at an ontological level. Capitalism is a cultural as well as political and economic system and political and economic practices must always be deconstructed and shown to be historically and geographically provincial.

Whilst acknowledging the power of this critique, this article will present both political economy and Floridian readings of the role of skilled international migrants in Tiger economies separately. For the moment, the notion of dialogue will be preferred to synthesis, integration and/or unification, not least since it is imperative to keep in mind the different objects of enquiry each perspective foregrounds: skilled international migrants and the creative class. Whilst occupying similar universes, members of the creative class clearly constitute only a subset of all skilled international migrants. In calling for literature on skilled international migration to open up to the insights of the creative class thesis, it will be necessary to exploit some blurring of the boundaries between each constituency. But for the moment, the theoretical integrity of each tradition will be respected.

Given the complex ways in which Tiger states have become integrated into the global economy, the pertinence of the creative class thesis is likely to vary significantly between them. In exploring the benefits which the creative class thesis might bring to explanations of the rise of Tiger economies, this article will present a case study of skilled migration to one Tiger state in particular, the Republic of Ireland. The Republic of Ireland represents the most profitable meeting point for both bodies of scholarship as it has been explicitly claimed by each as a paradigm example. For Sean O'Riain (2000; 2004), for instance, Ireland stands as a classic Tiger economy not only because of its rapid economic growth in the past decade but more importantly because growth was commanded by a developmental state that shares the same family roots as many of the Tiger economies of Pacific Asia. Meanwhile, alongside Austin Texas, Florida cites the Celtic Tiger and in particular Dublin as a showcase example of a city-region which is already proof positive of the validity of his entire thesis (Florida, 2002: 300-2).

This article is structured around two sections. In the first section, the utility of bringing a Floridian perspective to bear on the case of the Celtic Tiger is further elaborated. Following a relatively straightforward political economy reading of skilled international migration to the Celtic Tiger, Florida's ideas will then be introduced and their significance for flows of talent to Ireland explained. Section 2 of the article will then report upon the findings of ten focus groups which were conducted with skilled Scottish expatriates working in Dublin in the summer of 2003. Here the objective will be to assess the extent to which the creative class thesis is capable of explaining the relocation decisions of Scottish workers; in other words, whether there is any evidence that skilled Scots are moving to Dublin in response to the city's ability to service their basic cultural needs. 
Florida's creative class thesis and the role of cosmopolitanism in the rise of the Celtic Tiger

A political economy reading of skilled international migration to the Celtic Tiger

Already one of Europe's poorest nations, the Irish Republic suffered a prolonged economic depression throughout the 1980s. Remarkably, however, from 1993 onwards, the country witnessed a spectacular reversal in its fortunes. Between 1991 and 2005, GDP per capita grew from 79\% of the EU-15 average to 125\%. Between 1995 and 2002, in particular, the economy grew by an average of $8 \%$ a year, compared with the EU-15 average of $2.5 \%$ (Figure 1). In the early 2000 s, slower growth rates led pessimists to question whether the bubble had at last burst (Clinch et al., 2002). New forecasts suggesting a return to impressive if not spectacular growth (c. 5-6\%), however, would appear to have galvanized a renewed enthusiasm and rekindled a belief that the miracle is still alive (Central Bank and Financial Services Authority of Ireland, 2005).

There is now a vast literature which seeks to explain Ireland's economic success (O'Hearn, 1998; 2000; 2001; Allen, 1999; Taylor, 2000; McSharry and White, 2000; Ferreira and Vanhoudt, 2004; House and McGrath, 2004; Hardiman, 2005). As the label 'Tiger' increasingly came to be associated with the country, so too its growth strategy has come to be compared with its Pacific Asian counterparts. According to O'Riain (2000; 2004), this comparison is useful as Irish economic growth was marshalled by a type of developmental state that derives from the same family of command capitalism practised in the dragon economies. In place of the highly centralized and interventionist roles played by state technocrats in Pacific Asia, however, the Irish state has operated with a more flexible and decentralized command structure and has exercised a much lighter touch.

On this basis, O'Riain argues that whilst the Pacific Asian economies are characterized by a bureaucratic developmental state, Ireland has grown under the governance of a new type of flexible developmental state or developmental networked state. For O'Riain, Ireland's flexible development state has been centrally implicated in brokering three interacting but empirically distinctive modes of integration into the global economy:

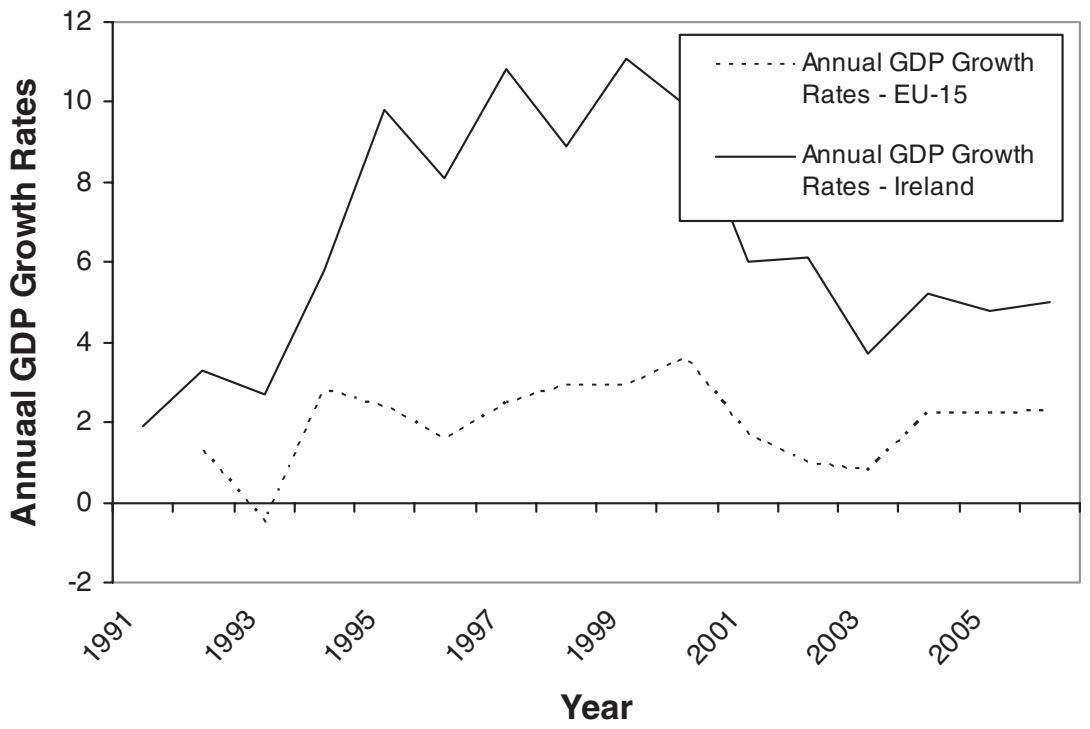

Figure 1 Annual GDP growth rates, EU-15 and Ireland (source: Eurostat, 2004) 
The first, and most widely recognised is built around attracting foreign investment and to a limited degree embedding it into the local economy. The global goes local. The second, and most surprisingly given Irish economic history, is the emergence of a local network of indigenous firms that have become increasingly integrated into international business and technology flows and have been highly successful in international markets. The local goes global. Third, a series of national neo-corporatist social partnership agreements since 1997 have created a stable macroeconomic and financial environment that has underpinned industrial transformation, while mediating the relationship of unionised workers and welfare recipients to the global economy. The national level mediates local adjustment to the global (O’Riain, 2000: 184).

As Ireland's economy has expanded, so too its labour market has tightened. In 1992, unemployment stood at $15.4 \%$ and compared unfavourably with the EU-15 average of $8.9 \%$. By 2004 unemployment was down to $4.5 \%$ compared to the EU-15 average of $8.1 \%$ (Figure 2). In the same period the total size of the workforce has grown by over 600,000 , from around 1.4 million to over 2 million. Even with relatively high fertility levels (Figure 3), growing female participation in the workforce, and major investment in upgrading the technical skills of the population (Wickham and Boucher, 2004), the labour market has been operating at full capacity. Against this backdrop, it is not surprising that Ireland has witnessed a remarkable reversal in its long tradition as a major exporter of people (Figure 3). The Celtic Tiger's insatiable appetite for labour has dramatically increased the volume of people now relocating to Ireland and it is questionable whether the country could have enjoyed economic success without immigration.

In spite of the rapidity of the growth of the Irish economy and the significant expansion of immigrant inflows, immigration policy in Ireland remains broadly intact from the days when it was a major exporter of people (see Immigrant Council of Ireland 2003 for an overview of the regime). Nationals from EU member states (including the ten accession states who joined in 2004), those from the wider EEA area, and Swiss nationals can freely work and live in Ireland. High-skilled workers from further afield can move subject to obtaining 'work visas' which are granted to employees in sectors suffering skill shortages for a period of two years initially with the possibility of renewal.

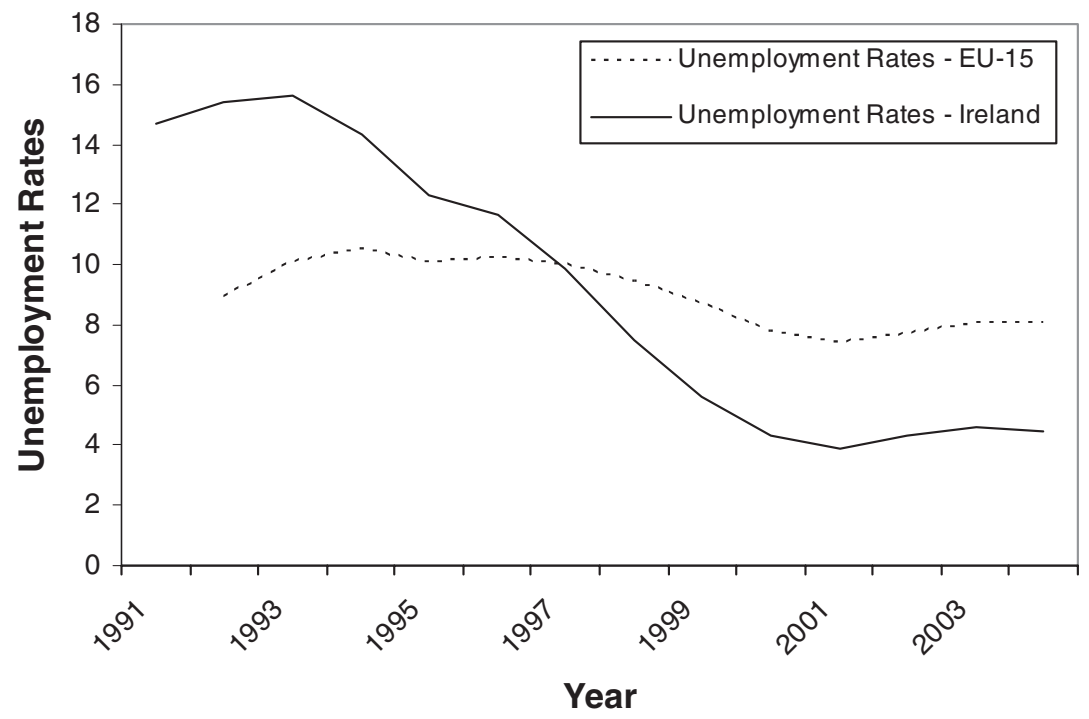

Figure 2 Unemployment rates, EU-15 and Ireland (source: Eurostat, 2004) 


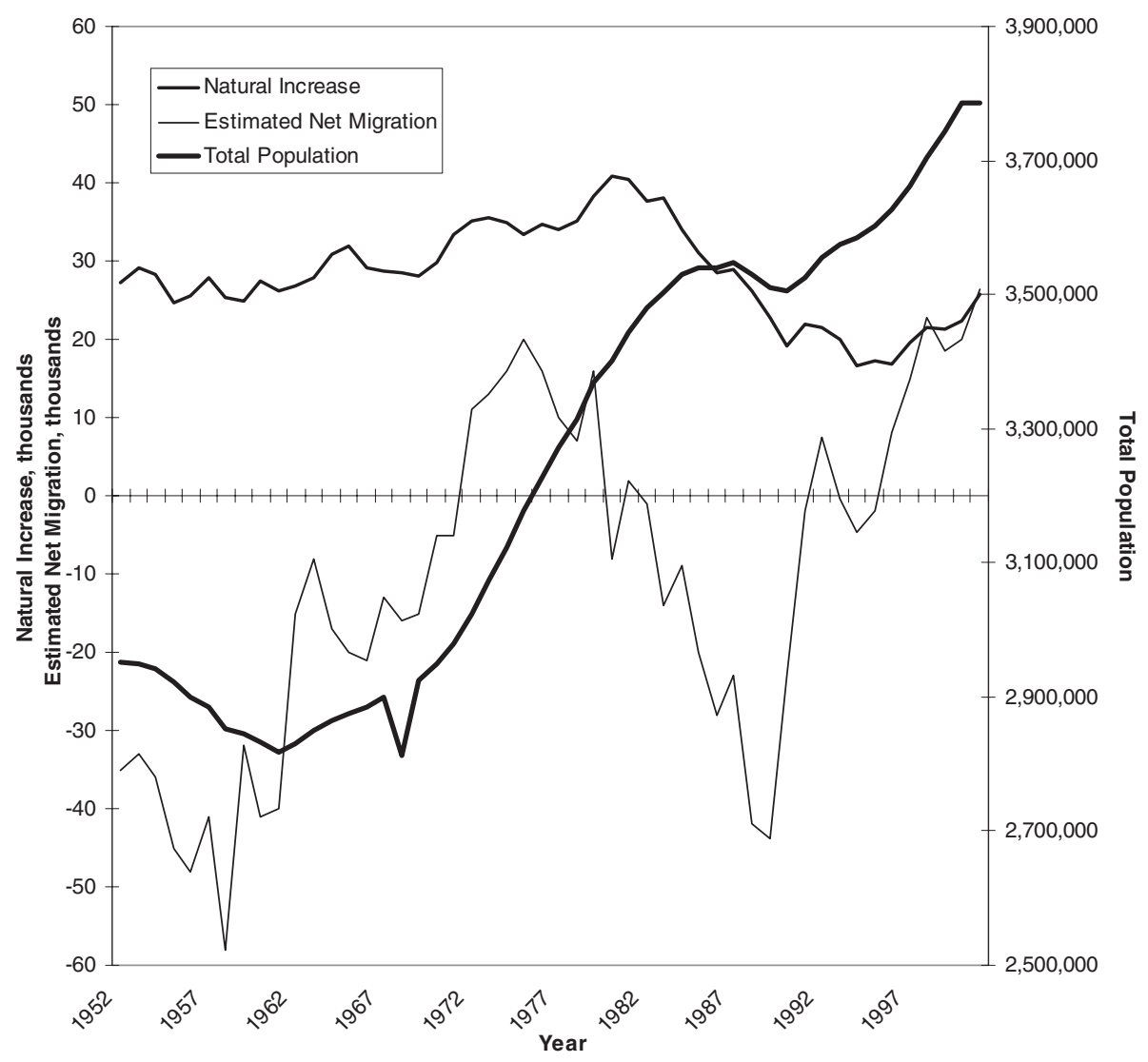

Figure 3 Demographic changes in Ireland, 1952 to present (source: Central Statistics Office 2005)

Entrepreneurs wishing to set up a business in Ireland can also apply for 'business permission permits' which entitle them to 12-month residency initially, subject to the new start ups employing two Irish or EEA nationals and the transference of a significant bond to the state. Meanwhile, the 'Intra Corporate Concession scheme' allows transnational corporations to relocate employees working in their internal labour markets to Ireland for a period of four years in the first instance.

Whilst outdated, this system has in fact served the high skill needs of the Celtic Tiger well (McGlaughlan and Salt, 2002) - albeit proving to be oppressive to low-skilled workers (Valarasan-Toomey, 1998; Allen, 1999). Within this legislative framework, recruitment agencies, FAS (Ireland's labour market and training agency) and large companies themselves have been able to successfully prospect for talent abroad.

Exemplifying the interventionism which characterizes Ireland's flexible developmental state, FAS has recently predicted that bottlenecks in the labour market will become serious unless immigration policy is given a root and branch overhaul (FAS, 2004) According to FAS, Ireland needs to attract even more highly skilled engineering, information and communications technology (ICT), health and other professionals and skilled workers as a matter of urgency if impending bottlenecks in physical, knowledge and social infrastructures are to be removed. Debate is ongoing as to the forms which any new regulatory apparatus might assume. 
The growing number of foreign workers entering the Irish Republic needs to be contextualized against the backdrop of O'Riain's claim that the country exhibits three distinctive modes of integration into the global economy. Whilst it is beyond the scope of this article to link specific flows of labour to each of these modes of integration (but see McPherson and Roche, 1997), some basic pointers can be given (see Table 1).

- Firstly, whilst in the period 1986-91 annual net migration stood at $-26,800$, in the period 1996-2002 annual net migration registered $+25,600$. Moreover, from Table 1, it is evident that between 1991 and 2002, the net addition of over 170,000 foreignborn residents has brought the total number of foreigners to approximately 400,000, or $10 \%$ of the total population.

- Secondly, in the period 1996-2002, between $40 \%$ and 50\% of all annual inflows represented returning Irish nationals who had fled abroad when times were bleaker in the past. To the extent that returning diasporeans bring with them the added advantage of a global business acumen, it would be profitable to enquire into the degree to which they are playing an important role in brokering Ireland's global command and control capabilities.

- Thirdly, of the foreign born arrivals since 1991, 44\% have come from the UK and 9\% from the other EU-15 excluding the UK. This suggests that there is a high skill regional migration system being established within western Europe but that the historical ties that bind Ireland to the UK have ensured that the UK has dominated as a principal source region.

- Fourthly, given the insertion of Ireland into the international divisions of labour created by US TNCs, it is unsurprising that America continues to dominate the rest of the world category. Nevertheless, it is clear that flows of skilled labour from Australia and New Zealand have also grown in importance. Given the general absence of Antipodean TNCs these migrants have presumably moved at their own behest and have entered the local labour to be picked up by companies seeking professional, technical and managerial expertise.

Table 1 Persons usually resident in the Republic of Ireland and present on census night classified by place of birth, 1991, 1996, 2002

Birthplace

Number

1991

1996

2002

\begin{tabular}{lrrr}
\hline Total & $3,525,719$ & $3,596,543$ & $3,858,495$ \\
\hline Republic of Ireland & $3,296,994$ & $3,344,919$ & $3,458,479$ \\
\hline Outside Ireland & 228,725 & 251,624 & 400,016 \\
\hline EU 15 & 190,978 & 209,880 & 281,316 \\
\hline EU (excluding UK) & 17,127 & 19,232 & 32,801 \\
\hline England and Wales & 126,487 & 139,330 & 182,624 \\
\hline Northern Ireland & 35,986 & 39,567 & 49,928 \\
\hline Scotland & 11,378 & 11,751 & 15,963 \\
\hline Rest of world & 37,747 & 41,744 & 118,700 \\
\hline America (including South) & N/A & 19,913 & 29,119 \\
\hline Antipodes & N/A & 3,636 & 8,363 \\
\hline Other European & N/A & 3,605 & 26,235 \\
\hline Asia & N/A & 8,150 & 28,132 \\
\hline Africa & N/A & 4,867 & 26,515 \\
\hline
\end{tabular}

Source: Central Statistics Office (2005) 
- Finally, recent arrivals have been biased in favour of non-conventional source regions resulting in a far broader mix of foreign-born workers. The fastest rates of growth have been recorded amongst inflows from central Europe, Asia and Africa. It is likely that it has been these migrants that have serviced the less glamorous but equally important dirty, dangerous and low-paid occupations.

\section{An introduction to the creative class thesis}

Richard Florida's work demands attention. On the back of the publication of his best seller The Rise of the Creative Class in 2002, the high volume of traffic which has visited his glossy website, a series of high-profile promotional speaking tours in North America, Australia and Europe, and the growing influence of his Pittsburgh- (now Washington-) based consultancy company Catalytix, Florida has emerged as something of a celebrity figure within the North American practitioner community and a near messiah for some city mayors and governors.

Amidst the flotsam of policy debates, populist newspaper articles, and the chatter which has been fuelled by self-promoting Florida-style websites, it is important to realize nevertheless that Florida is as much a public intellectual as he is a theoretician of urban and regional growth and that The Rise of the Creative Class is in the end quite a lightweight academic work. Indeed for some, Florida is intriguing not so much for his thesis but for the insights he furnishes into how academic ideas come to be produced, circulated, popularized and policed in the increasingly congested traffic lanes powered by the global academic industry (Gibson and Klocker, 2004).

It is important then to assess carefully what the creative class thesis has to offer literature on Tiger economies. Florida (2002) begins with the bold assertion that the class structure of capitalist societies is currently undergoing tumultuous change at the heart of which a new 'creative class' is coming to the fore. Whilst the availability of stocks of technology remains a necessary condition for urban and regional development, it is increasingly becoming an insufficient determinant. According to Florida, the quality of human capital in any place, and more particularly the membership base of the 'creative class' in that place, is now as important — if not more important — in driving economic growth. Consequently, luring members of the new class to one's city or region is a policy imperative.

The creative class is comprised of a 'super creative core', which consists of a new class of scientist and engineer, university professors, poets, actors, novelists, entertainers, artists, architects and designers, cultural worthies, think-tank researchers, analysts and opinion formers, 'whose economic function is to create new ideas, new technology, and/or new creative content' (Florida, 2002: 8). Beyond this core group, the creative class also includes a wider circle of talent working in knowledge-intensive industries such as high-tech sectors, who "engage in complex problem solving that involves a great deal of independent judgement and requires high levels of education or human capital' (ibid.) Whilst recognizing that 'there are grey areas and boundary issues', Florida asserts that the notion of the creative class 'has a good deal more precision than existing, more amorphous definitions of knowledge workers, symbolic analysts, or professional and technical workers' (ibid.) and on this basis confidently asserts that around 38 million or $30 \%$ of all employed people in the United States belong to this class.

Given the central role they play, it is crucial that cities and regions re-engineer themselves so that they offer the right package of attractions to the creative class. It is here that Florida regards culture to be at least as important - if not more important as economic opportunity and labour market conditions. 'Cool places', which transcend distinctions between the bohemian and the bourgeois ethic, which provide 'low entry barriers', which offer 'plug and play communities', and which promote tolerance, diversity, creativity and 'boho chic' will offer the greatest lure in future. The policy diagnosis, therefore, is for places to transform themselves from stuffy, conservative, 
insular, parochial, bureaucratic and stifling 'working class enclaves', 'boring postindustrial service centres' and 'high technology 'nerdistans', into liberal, bohemian, multicultural and culturally cosmopolitan hubs.

Based upon a number of indices variously titled the 'creativity index', the 'gay index', the 'bohemian index' and the 'melting pot index', and focus group analyses with members of the creative class, Florida identifies cities like San Francisco, Austin, San Diego, Boston and Seattle as exemplars of the preferred habitat. In contrast places like Memphis, Norfolk, Buffalo, New Orleans and Oklahoma City stand as repellents to the creative class. Correlating creative places with measures of talent (including the 'talent index'), and technology (the 'high-tech' index, the 'innovation index' and so on), Florida claims to have empirical evidence which establishes that it is those places that score highest for their openness and diversity which are also proving to be key magnets for talent and drivers of technological progress.

\section{'Cosmopolitanism' and skilled international migration to the Celtic Tiger}

Florida's evangelical zeal has not been confined to North America and recently his policy prescriptions would seem to be 'going global' with alarming speed. Perhaps most surprisingly, he has emerged as something of a guru and talisman in a number of north European nations, regions, and cities in particular. In Europe in the Creative Age (Florida and Tinagli, 2004), and The Flight of the Creative Class (Florida, 2005a), Florida argues that Europe stands on the brink of challenging the United States as the leading draw for the global creative class. Within Europe, the traditional powers, especially France, Germany and the United Kingdom, look set to lose out to a cluster of cosmopolitan hubs in Scandinavian and northern European countries. Sweden, Finland, the Netherlands, Denmark and Belgium all now serve as better habitats for the creative class and ought to be the most dynamic economies in the future.

Whilst starting off from a low base, the Republic of Ireland has also grown to become one of the most significant hot spots for creative talent. Indeed, Ireland's primate city, Dublin, is cited by Florida (2002: 300-2) as a world-class example of the validity of his entire thesis. Intriguingly, however, Florida and Tinagli (2004) also note that, based on their so-called 'Euro tolerance index', the Irish Republic stands as one of the least cosmopolitan and tolerant nations in Europe. The Euro-tolerance index represents a composite measure based on attitude surveys (examining racism and xenophobia), values surveys (examining the degree to which a country reflects modern and secular values towards God, religion, nationalism, authority, the family, women's rights, divorce and abortion), and self-expression surveys (examining attitudes toward self-expression, quality of life, democracy, science and technology, leisure, the environment, trust, protest politics, immigrants and gays). To the extent that this index is an effective measure of tolerance, questions could be raised as to whether the Republic of Ireland in fact presents a challenge to the creative class thesis.

Whilst it is true that its unique social, political and cultural history in the twentieth century did render Ireland a nationalistic, conservative and insular country on the margins of Europe, for at least five reasons it now makes sense, alongside political economy frameworks, to also enquire into the extent to which skilled migrants move to Dublin in particular because of its status as a cosmopolitan capital.

- Firstly, as noted above, rising immigration in the past decade has brought returning 'internationalized' diasporeans back to Ireland, swollen the number of foreign-born nationals to a historical all-time high, and diversified the country's immigrant stock (Immigrant Council of Ireland, 2003).

- Secondly, there has been considerable debate in Ireland over the extent to which its rapid integration into the world economy has triggered widespread secularization and a new outward looking post-colonial national identity (Fagan, 2002; Kirby et al., 2002). 
- Thirdly, after a relatively slow start, cultural and tourism policy has vigorously sought to exploit the nation's cultural, artistic, and literary heritage and has offered tax breaks and other incentives to contemporary artists, film makers, media moguls and writers to promote urban and regional growth (Lennon and Seaton, 1998; Bayliss, 2004a; 2004b).

- Fourthly, successive waves of urban regeneration in Dublin have created a number of new cosmopolitan quarters, including the recently gentrified Docklands area, the café and culture scene in the Temple Bar zone, and the restoration of O'Connell Street as a sweeping boulevard in the European tradition (Bartley and Treadwell-Shine, 2003).

- Finally, Dublin City Development Board's latest plan for the city - Dublin: a city of possibilities (2002-2012) — has placed cosmopolitanism, cultural mixing, openness, tolerance and cultural inclusion at the heart of future decisions on land use, urban design and planning (Millington and Young, 2003).

\section{The adventures of Scottish expatriates in Dublin}

\section{Methodological preface}

The United Kingdom evidently serves as a key source region for skilled workers relocating to the Irish Republic and within this flow Scottish expatriates constitute a significant and rapidly expanding force; the net addition of 4,585 Scots between 1991 and 2002 has allowed this community to grow to almost 16,000 (Figure 3). In seeking to explore the salience of cosmopolitanism and creativity in the relocation decisions of skilled employees moving to the Celtic Tiger, a case study of the Scottish expatriate community currently living and working in Dublin will be presented. In no sense can this constituency be said to be representative of all skill flows to Ireland but it does serve to provide an interesting test case for three reasons.

Firstly, after three decades of mediocre economic growth, Scottish economic policymaking is currently the subject of hot debate (Coyle et al., 2005; Devine et al., 2005). Moreover, in considering options, politicians, academics, and policymakers and practitioners have turned towards Ireland for guidance (Alexander, 2003; Krugman, 2003; Bradley, 2005). Secondly, in the light of falling birth rates (Randall, 2002; Joshi and Wright, 2005) and fears that a number of key economic sectors will be threatened by skill shortages as a result of retirement (Future Skills Scotland, 2002; Brown and Danson, 2003), the Scottish Executive has established the procurement of skilled labour as a crucial economic development priority (Fresh Talent Scotland, 2004). Finally, reflecting the reach of Florida into European urban and regional policy communities, there has been much debate in Scottish economic policy circles over the extent to which Scotland is cosmopolitan enough to attract skilled talent (Harrison and Mason, 2003). This debate has been fuelled by the unscientific but widely held suspicion that Scotland is a stuffy, insular, parochial and conservative cultural backwater and as such is an unattractive proposition for creative talent (Craig, 2003). It has led to a number of high-profile anti-racist and anti-sectarian campaigns (including the One Scotland, many cultures campaign) which promote Scottish cities as 'cosmopolitan as well as metropolitan'.

In seeking to probe into the thoughts and feelings of Scots living and working in Dublin, the first challenge was to identify expatriates who might be prepared to share their experiences. A variety of methods were used to generate an initial contact list of 76 Scots. Among the more successful were the following: face-to-face contact with companies based in central Dublin; following through Scottish expatriate databases (for example, databases held by the Institute of Chartered Accountants in Scotland, Talent Scotland, and Strathclyde University Alumni); sourcing people through friends and colleagues based in Dublin; contacting human resource departments of large companies 
based in Dublin; approaching heads of departments, secretaries and student bodies in universities and colleges in Dublin, and recruiting customers on Aer Lingus flights from Glasgow Airport to Dublin.

Once the initial contact list had been established, the objective then was to include only those Scots who could be identified as skilled employees. A decision was taken to include all workers who fell into the Registrar General's socio-economic categories 1, 2 and 3 (non-manual and manual), taking the initial contact list down to just 53. Clearly not all skilled workers fall within Florida's creative class schema. Whilst it is true that a case might be made that creativity plays a large part in the roles performed by most of these employees, it is important that the distinction between skilled workers on the one hand and creative talent on the other is preserved. The purpose of the research was explicitly to gauge the extent to which the creative class thesis was capable of shedding light on the locational choices of skilled migrants more generally.

Having filtered the initial contact list, the overall objective of the project then became to learn more about the experiences of Scottish expatriates living and working in Dublin. Given the small size of the contact list, and more importantly the fact that the survey method was judged to be too blunt to probe into migrants' decision-making processes, a decision was taken to conduct ten focus groups consisting of five expatriates in each group. Again, due to the small size of the contact list and the obvious logistical difficulties of bringing busy people together, no effort was made to structure groups based upon occupation, age, gender, date of migration and so on. In fact, the mixture of participants in each of the groups eventually proved to add to the richness of the discussions.

In the end, ten focus groups were completed, between 6 May and 21 August 2003 (Boyle and Motherwell, 2005). Due to participant recruitment difficulties, only 38 expatriates eventually took part, resulting in an average of 3.8 expatriates per group. An overview of the participants is provided in Table 2. Among the key features of the cohort to keep in mind when interpreting the focus group findings are the following:

- Consistent with the age profile of all migrants to Dublin, young adults emerged as the dominant stream (nearly 90\% were between the ages of 18 and 35).

- The majority of the participants were not in committed relationships and were relatively footloose in regards to personal ties (nearly three-quarters were single).

- Three-quarters of participants were men. Given that it is known that in-migration to Dublin in the past decade has involved an equal proportion of men and women, this suggests that either the Scottish influx is unrepresentative, or more likely that males were more inclined to respond to the focus group invite.

- The vast majority of participants had migrated to Dublin very recently, with nearly 90\% arriving from 1998 onwards.

- Less than a quarter of migrants had bought property in Dublin, highlighting both the transience of the migration and the cost of housing in Dublin.

- Participants hailed from a wide range of geographical origins in Scotland and the West of Scotland was not the only source of migrants.

- Perhaps surprisingly, only a minority had Irish ancestry, indicating that this is not a phenomenon driven primarily by historical family connections with Ireland or diasporic nostalgia.

- Finally, although participants span a wide range of occupational and salary scales, nearly two-thirds came from the accountancy and finance, ICT, and hotel and catering sectors.

Given that only 38 of the estimated 16,000 Scots who are based in the Irish Republic participated in the research, no claims can be made as to the representativeness of the results reported herein to even this small expatriate community. As is the case with most qualitative research, the objective of the project has been principally to gain insights into the perceptions and attitudes of Scottish expatriates, those softer aspects of 
Table 2 Summary breakdown of the focus group participants*

\begin{tabular}{|c|c|c|c|c|}
\hline Question & $\%$ & & uestion & $\%$ \\
\hline 1. Age & & & Occupation & \\
\hline $18-25$ & 29 & & Managers or senior professionals & 13 \\
\hline $26-35$ & 61 & & Middle managers, professional or highly skilled & 37 \\
\hline $36-45$ & 8 & & Associate professional or skilled manual & 32 \\
\hline $46-55$ & 3 & 8. & Sector & \\
\hline 2. Gender & & & ICT & 30 \\
\hline Men & 74 & & Accountancy and finance & 18 \\
\hline Women & 26 & & Hotel and catering & 18 \\
\hline 3. Origins in Scotland & & & Construction & 5 \\
\hline Lanarkshire \& West Lothian & 29 & & Utilities (telecommunications) & 8 \\
\hline Ayrshire & 16 & & Engineering & 5 \\
\hline Glasgow & 16 & & Health/welfare & 8 \\
\hline Edinburgh & 13 & & Retailing & 8 \\
\hline Borders & 8 & 9. & Date of migration to Dublin & \\
\hline Fife & 8 & & 2003 & 5 \\
\hline Inverness & 5 & & 2002 & 13 \\
\hline Dumfries \& Galloway & 5 & & 2001 & 26 \\
\hline 4. Irish roots in the family & & & 2000 & 32 \\
\hline Yes & 55 & & 1999 & 5 \\
\hline No & 45 & & 1998 & 8 \\
\hline Yes, first generation & 6 & & Pre 1998 & 11 \\
\hline Yes, second generation & 41 & 10. & Length of time in present job & \\
\hline Yes, third generation & 35 & & Under 1 year & 13 \\
\hline Yes, fourth generation & 20 & & $1-3$ years & 72 \\
\hline 5. Marital status & & & 3-5 years & 16 \\
\hline Single & 79 & 11. & No. of jobs since migration & \\
\hline Married & 18 & & One job & 48 \\
\hline Divorced & 3 & & Two jobs & 23 \\
\hline 6. Salary (Euro) & & & Three jobs & 6 \\
\hline $15-25,000$ & 18 & & Four jobs & 18 \\
\hline $25-30,000$ & 26 & & Five or more jobs & 5 \\
\hline $30-35,000$ & 16 & 12. & Tenure & \\
\hline $35-40,000$ & 5 & & Rent & 73 \\
\hline $40-45,000$ & 8 & & Owner/occupier & 23 \\
\hline $45-55,000$ & 13 & & Other & 4 \\
\hline $55-70,000$ & 6 & & & \\
\hline $70,000+$ & 8 & & & \\
\hline
\end{tabular}

*The total number of participants was 38 and percentages are rounded up.

Source: Author's survey 
migrants' decision-making processes that are simply not accessible to survey methods. This qualification noted, the analysis which follows has attempted to include only those themes that surfaced persistently in groups and which would appear to have a more general significance. I would therefore want to argue that the conclusions reached are not unique to only the 38 individuals who took part.

\section{The adventures of Scottish expatriates in Dublin}

Used to his otherwise slick turns of phrase, the reader cannot help but be alarmed at the long subtitle accompanying Florida's The Rise of the Creative Class 'and how it's Transforming Work, Leisure, Community and Everyday Life' (Florida, 2002). In choosing a rather cumbersome subtitle, Florida is clearly keen to emphasize the ways in which members of the creative class are currently transforming work, lifestyle and everyday routines, and community life. Alert to the significance of these distinctions, the following analysis will be structured around Florida's claim that cosmopolitan places attract creative talent on the basis of the alternative attitudes to work they promote, their tolerance towards new lifestyles and promotion of innovative everyday routines, and the porosity of their community structures.

\section{Workplaces that offer the freedom to breathe and to become}

According to Florida, the creative class are at their best in the 'no collar workplace', where hierarchical and bureaucratic company structures and regimes of surveillance are replaced with new forms of 'soft control' which include self-management, peer recognition and pressure, and intrinsic motivation. The creative class both contribute to and benefit from revolutionary changes in the workplace, which seek to replace fossilized Fordist and Taylorist ways of working with flexible and stimulating working practices. To what extent have Scottish expatriates found working life in Dublin to be comparatively more liberating than that on offer in Scotland and how significant have workplace cultures been in their relocation decisions?

An interesting initial finding was that only one participant had been channelled into Dublin via the internal labour market of a TNC, in this case a TNC operating in the hotel and catering sector. The overwhelming majority had made their way to Dublin independently. When asked why they relocated to Dublin, by far and away the most pervasive explanation advanced was the city's outstanding career opportunities. Advocates of this viewpoint most often began by noting that Dublin offered a 'way out' for Scots suffering the ignominy of struggling to find careers and salaries appropriate to their education and skill levels back in Scotland. Many bemoaned the extent to which graduates were confined to working in 'call sector factories' for want of more appropriate employment. The lack of career opportunities in Scotland was leading to a frustration that was making migration inevitable:

I think the main reason I came over was because there was no work at home. People were getting degrees and honours degrees but still couldn't get any work. There is no point in studying hard in Scotland and working hard in Scotland and by the time you finish your education you are struggling to get a job, and when you do get a job you're not really getting enough to live on, or you are just scraping by so that its not really worth putting yourself through all the hard work to stay in a place and not benefit from it.

Time and again, participants would then point to their disbelief with the ease with which they could pick up work in Dublin. This disbelief was extended to include not only the ubiquity of employment per se, but the comparative superiority of careers and salaries available in the city. The possibility of working for large multinational companies with no presence in Scotland, the potential to undertake higher-level functions, the enhanced possibility of accelerated promotion and the capacity to assume unprecedented responsibility for one's age, were all definitive themes: 
It's just easier to get into better roles and to move up the ladder. You would like to think that if you moved back to Scotland you would slot into the same place but I very much doubt that and I think even getting really good experience here you would still be knocked down a peg or two back in Scotland because the opportunities are not the same.

To some extent, Ireland's successful recruitment of Scottish talent can be attributed to the aggression and innovation of its army of producer services. For many participants, the decision to move to Dublin was mediated by Irish-based recruitment agencies, executive selection firms, executive search companies, FAS recruitment exhibitions, and by the human resources departments of major employers:

I came out of university and had a few job interviews in England, IBM and stuff like that. I went to Birmingham and it was like a cattle market, roughly three hundred people go and it was just a nightmare. I sent one e-mail to Bond Recruitment in Dublin, within half an hour the guy got back to me and said he worked for a large IT company in Dublin. I said, you cannot have read my CV, it's only been half an hour. Within 2 weeks he got me an interview. It was chalk and cheese. I had been looking for about three or four months for a job. The recruitment companies here are totally different from the ones in Scotland. The ones in Scotland you go in and you give them your CV and they just say thanks. And you know its going straight in the bin once you are out the door. Here it was lock the door, this guy has got experience in IT, they were so desperate for anybody. It was a real culture shock, to come over here and actually the ball was on your side of the court. Instead of chasing jobs, jobs were chasing you.

These firms have also been proactive in placing adverts in the Scottish press, organising trade fairs in Glasgow and Edinburgh, soliciting records of employees working in Scottish companies, and harnessing the Internet in innovative ways to recruit Scottish talent. Indeed, they would appear to be so aggressive that they had managed to dislodge one participant from a settled life back in Scotland who had no intention of migrating to Dublin prior to being lobbied:

Actually I didn't want a job over here. I was quite happy working away in Glasgow. Then I got a phone call from an agency one day asking if I had heard of the company. And apparently they were quite well known, they had knocked Scottish and Newcastle out of the FTSE 100 and all that sort of stuff. I said I don't fancy it but I went across for a free weekend. They offered me the job and I was saying what am I doing, why am I leaving my friends and family. I didn't want it but they had offered eight people it before. They couldn't get somebody.

Scottish expatriates are choosing to migrate to the Celtic Tiger then, primarily because of the superior salary scales and career opportunities on offer and they are being made aware of these opportunities and encouraged to relocate by proactive Irish recruitment practices. This is not to say, however, that Florida's assertions about workplace culture are not important. A fascinating result to derive from the focus groups was the widespread comparisons that were drawn between working life in Scotland and working life in Dublin. Indeed, this point was raised in all ten focus groups and was the most discussed issue in the majority of the groups. Although not responsible for their initial decisions to move, as they settled into Dublin many participants have become acutely conscious of the city's more liberated employment regimes.

For at least this small survey cohort, the results would seem to confirm the suspicion that Scottish workplaces are failing to cultivate conditions that are maximizing the creative potential of their employees. Scottish businesses were characterized as being hierarchical, bureaucratic, unfriendly, rigid with time keeping and routes to promotion, conservative and stifling. For many people, this atmosphere was experienced as demotivating, unprofessional, and suffocating. In comparison, Irish-based businesses were universally acclaimed for being more relaxed, friendly, less intimidating, more professional, more trusting of their employees, more flexible, and in general more supportive of the flourishing of the creativity of the employee: 
What is really obvious is the difference in attitude to work. I find that Scottish people tend to problematize everything. It's a real negative trait that we go around making problems that don't exist. I really noticed that when I worked here for a year and then went back briefly to Scotland. Even meeting politicians or project leaders, and various people from the community is different. Here everyone is on first name terms. And you can have lots of informal chats about issues and you know you are getting into someone's ear. In Scotland, I found the structure and the bureaucratic hoops that you have to go through stifling.

When I worked for a law firm in Edinburgh, I always felt that somebody was watching you leave and you leaving the desk for ten minutes was punishable by death, being thrown out of the window! I've certainly benefited from being a lot more open in working here, and therefore it's kind of produced a little more creativity in my working environment because I feel it's going to be rewarded. You know they say if you have any ideas, if you feel you can change things, please tell us. And it's actually taken up upon, not stolen or you are not told you are too far down the ladder to do anything or suggest that. Rather it is embraced and taken up upon and it just makes your whole work worthwhile.

Unfortunately, groups did not explore whether the unique cultural ambience of the Dublin workplace was a function of working regimes introduced by North American transnational companies or simply reflected a disposition within Irish management circles to supervise staff in this way. Whatever the source, among the key features of working life in Dublin that appealed to participants were the following:

- Flexible working hours

- Greater trust over timekeeping during the day

- A greater feeling that one's ideas are being listened to

- A greater confidence that one is getting recognized for one's ideas and that these ideas are not being appropriated by higher-level management

- A blurring of the boundaries between social and work relationships both within and between different levels of management

- An irreverence for petty red tape

- A more relaxed attitude to work attire

- Promotion based upon talent and not time served

- Greater emphasis upon more lateral approaches to problem solving

- The fostering of a more 'human' and 'fun', as opposed to 'mechanical' and 'efficient', office ambience

- An architectural design of the work place that is less hierarchical and more geared to team building.

For many participants, the result of Irish working practices was a more playful, innovative, satisfied and motivated workforce. It would be misleading, however, to fail to report the voice of a minority of Scots who were finding it difficult to square their outlook on work with that of the Irish. Whilst most participants argued that freedom brought with it a sense of responsibility and greater efficiency and productivity, some saw in the Irish only a lax attitude that was breeding laziness and inefficiency, and which was providing a frustrating climate in which to work and in which to achieve results in a certain time frame:

For me it is more laid back, but there are two sides to it. To contrast it with the UK, there is a lack of stupid rules and look as if you're busy when you're not - the nonsense like that. They lack the kind of bosses who have been there for 30 years and you know have to justify their existence. At times though, it is frustrating as you want to get things done. I find the attitude is that if something can be left till tomorrow to get done it will be left until tomorrow. There doesn't seem to be any sense of urgency to get things done. When you are doing your work then its great but when the bus driver doesn't turn up because they can't be bothered, that is the flip side.

Interestingly, many Scots felt that the balance they brought to the table - a mixture of Scottish application and Irish flexibility - was the key to the success they were 
experiencing in Dublin. The optimum for one participant in particular, was to 'hybridize the Scottish Protestant work ethic with Irish Catholicism's flair for the creative'.

\section{Everyday life and the lifestyle and lifecourse 'morph'}

According to Florida, the creative class aspire to active and busy lifestyles that facilitate the consumption of new experiences and the 'deepening of the moment'. Concomitant with these new lifestyles, the creative class seeks to 'morph' orthodox conceptions of the life course and extend leisure habits which have previously been associated with the 'twenty somethings' across the lifespan. Cities which are open to alternative ways of living out the lifecourse, and which provide the soft infrastructure which underpins sensory and experimental consumption practices, will be preferred by members of the creative class. In what sense can Dublin be said to be a pioneer of the lifestyle and lifecourse morph?

Although comprising only a small minority of participants, what might be referred to as 'tumbleweeds' come closest to fulfilling Florida's assertion that Dublin is just such a city. Tumbleweeds represent migrants who would appear to be very footloose and open to being 'blown about' by factors only partially shaped by career ambitions. Three particular types of tumbleweed were most conspicuous in the focus groups. First, at the lower end of the labour market, tumbleweeds were workers in the service sector (for instance, in hotel and catering trades) who had simply grown bored with life in Scotland and who had heard about the 'buzz' and 'vibe' of Dublin and had casually decided to give it a go:

I'd been here for a weekend and enjoyed it. So I just came over, booked myself into a B\&B on Grafton Street and walked up and down O'Connell Street and Grafton Steet trying to get work in pubs and I got started in a job straight away. I done it pretty quickly. It was just one Thursday morning and I was in bed and I thought, I'm getting out of here. I packed in my job on the Friday and I was over here on the Tuesday. You know it just clicked, I don't like it here any more and I need to get away.

Second, further up the scale were recent graduates who wanted to 'live a little' before settling down into a life of responsibility and who thought of Dublin as the perfect party city to exorcise their adolescent rites of passage:

Dublin seemed to have a real buzz about it you know. I had been over before for a couple of weekends and had a really cracking time. As a place to drink it is fantastic. It's a great place to go out and meet people - people from all over the world - and have some real fun. I had been to Dublin a couple of times before and it was a party city. The Irish are really friendly you know, much more open and willing to talk to anyone, especially the Scots, I think because we have the same sort of humour you know. Even at work you know we are always going out, not just at the weekends but during the week too. It is part of life here. Drinking and having a good time.

Finally, and invariably offering skills at the higher end of the labour market, were the seasoned travellers who had perhaps already tasted travel around the world and for whom Dublin was on the world map as an exciting place to work for a few years:

I just fancied a change. I had heard a lot about Dublin and I had been in Australia travelling and decided to try Dublin. I had met a couple of Irish folk in Australia and it sounded really good.

For these tumbleweeds, Dublin was indeed a perfect incubator of the lifestyle and life course morph:

Dublin is a very cosmopolitan city. It has a very young population with a lot of disposable income. Most people I know in Scotland in the 20 to 30 age group are married with a house and kids and a brand new car. Whereas here, at 30 years old, people are still not interested in 
that kind of lifestyle. The lifestyle revolves around the social life and going out. The bulk of people's money is spent on drink, buying clothes and going out to restaurants.

Intriguingly, however, for the majority of participants, more traditional everyday pressures and life course concerns were impinging themselves forcibly. Whilst Dublin might be a conducive environment for now, it was not a place where one could envisage building a long-term future. Towards the end of each of the focus groups, participants were asked to reflect upon their future locational aspirations and whether they viewed Dublin as a possible permanent place of abode. There was a definite sense that Dublin was not the last stop. When asked about the factors that made Dublin unattractive as a permanent residence it became clear more orthodox everyday worries and life course demands were overwhelming the frivolities of the city's attractiveness as a 'plug and play' community:

For me, I really enjoy the social life here and the music scene so I think I have a different attitude in some respects. If I was wanting to settle down here then I think I would really question what sort of life I could afford to have. Dublin is a vibrant city but it is getting more and more expensive to live in and the salaries are not increasing to reflect that. I think my friends see it as one long weekend and are attracted by the social life here. The reality is a bit different. And I think after 1 or 2 years the novelty would wear off and you would start to get itchy feet. But it depends upon what stage in life you are at. I think it's mainly a great place for students to come over and experience.

As they reflected upon the ability of the city to function as a place in which to settle and build a new life, two traditional life course pressures in particular came to the fore: the quality of life 'costs' of living in the city, and the absence of family and friends. The quality of life costs of residing in Dublin emerged as a major source of frustration for expatriates. At one level, these costs simply referred to the escalating costs of living. Referring to 'rip off Dublin', one participant observed: 'My friends at home, they made a brilliant point, maybe by saying two or three years ago - oh Dublin is brilliant. Now they are saying, oh Dublin is really expensive. I have a friend at work who is on her fourth car loan and she doesn't even have a car. You are simply borrowing to live'.

Among the most expensive items mentioned were buying and renting property and car insurance and road tax:

Its really hard to settle down because of the house prices. The cost of living is huge. When you go back home you notice everything is cheaper. I mean I love it here and I'd really like to stay but I cannot get a foothold in the housing market. If I was earning the same wage in Scotland I could have bought a flat 4 years ago in Glasgow or Edinburgh. Then at least you could start settling down and have a better quality of life but here you know, you can only see 6 months ahead. There is no way I am going to pay $320 \mathrm{~K}$ for a house that might only be worth $80 \mathrm{~K}$. If there were cheaper houses I would have settled here quite happily. My mate bought a property for $300 \mathrm{~K}$ - if he had bought that in Spain it would have been a mansion. I ain't paying $300 \mathrm{~K}$ for a shed.

The general cost of living here is very high. You know car insurance back home costs between $£ 200$ and $£ 400$ a month. It is around $£ 1500$ here. Road tax in the UK is about $£ 250$ but here you can easily pay up to $£ 1000$. A comparison can also be made with the west end of Glasgow. You could share a flat up there for around $£ 275$ a month. Here you would probably pay up to $£ 400$ for the same flat. I don't think salaries are keeping up with the heavy cost of living. In my hotel, two middle managers even living together would find it very difficult to buy a house. It could take up to two hours to travel to work from an area outside Dublin they could afford.

In addition to the absolute cost of living, Dublin also scored badly on other more indirect quality of life costs. Among the many sources of complaint that were repeatedly brought up in the focus groups were the cost of health care and traffic congestion: 
The NHS in the UK has a bad reputation but it is a beacon of light compared to what you can expect here. To go and see a GP will cost you 40-50 Euro. And if you get a prescription saying you need medicine that costs 100 Euros a week, you need to pay that or you will not get the medicine.

It costs 40 Euros just to visit the doctors. And you don't want to take the risk with your children so you have to pay it. I think you can get some free prescriptions but there is a cut-off point - I think if you spend more than 80 Euro it is free after that. So from a family point of view, it can be very expensive.

The traffic is the worst thing. That is the one thing that really spoils my quality of life here. If I mis-time the rush hour traffic it sometimes takes me one hour forty five minutes to get home. The whole infrastructure is abysmal. Back home you have the Scotrail Network between Glasgow and Edinburgh, and the M9 and M8. Dublin doesn't even have a rail network, and you know the M50 isn't even finished yet. There is a toll bridge right in the middle of it which also jams things right up. This LUAS [a light railway] tramway thing they are building, its basically not going to do half of the things its supposed to do. The transport situation in Scotland is so much better than here.

The importance of non-substitutable family relationships and friendships represents another facet of Dublin's quality of life that was thought to be important in influencing future location decisions. Many of the participants noted that whilst they were not homesick, they did get people sick. This was most manifest when people were feeling vulnerable in Dublin (especially through illness), when people reflected on the mortality of their parents, and when they considered the importance of kin relations and education in the upbringing of their children. The emotional attachment to family and friends back in Scotland represents a major constraint on the mobility of at least some migrants:

One of the girls in our hotel is Irish and she went to work over in Edinburgh for a year and said it is just like being at home without your friends and your family. That probably describes my situation here. I simply don't have the same friends and family here. I think home will always be your home and it will always be like that.

\section{Cosmopolitanism and borderless communities}

According to Florida, the creative class thrives best in communities which are low in traditional forms of 'suffocating' social capital but high in forms of social capital which support easy entry, intense but shallow relationships, and acceptance of difference and individuality. Cities housing communities with porous borders are liable to be more attractive to members of the creative class than ones where strong communities render outsiders visible and subject to suspicion, judgment, inspection and surveillance. To what extent is Dublin such a cosmopolitan oasis?

A key feature of the Scottish diaspora in Dublin is the complete lack of a coherent and well organized expatriate community. The Scots have dissolved into Dublin and beyond, meeting socially for Scotland versus Ireland rugby games, football matches broadcast on satellite TV involving the 'old firm', or St Andrew's festivities and Burns nights, few see it as important that they mix and remain in contact with fellow Scots. ${ }^{1}$

Of course, diasporic communities most often tend to form in hostile environments as a psychological buffer assisting settlement. That a strong community does not exist lends support to the suggestion that Scottish people are finding Dublin a hospitable and cosmopolitan home. 
The fact that Dublin plays host to nationalities from all over the world does stand as a definite attraction to Scottish expatriates. Dublin is perceived to be a cosmopolitan vortex and a party city, full of colour and an exciting place to be. Experiencing other nations' ways of life, including their language, religions, customs and festivities, food, dress sense and folklore, was recognized to be a stimulant:

Dublin is one of the youngest cities in Europe and it also has a really cosmopolitan make up. Not only are there Europeans but there are Australians, East Europeans and so on. It's just so different to Kilmarnock and even Glasgow. There seems to be more excitement about Dublin because of its make up.

Moreover, Dublin would appear to offer the kind of manicured cosmopolitanism which Florida contends fosters precisely those intense but shallow relationships which are important to creative talent. Other cultures are sampled, not fundamentally engaged with. This sampling mainly takes the form of 'partying' with others. Cosmopolitanism is invariably interpreted in this context as a codeword for the vibrancy and demographic make up of the night-time leisure economy:

Dublin is so cosmopolitan it's untrue, here they drink every night, like during the week, it doesn't matter what night you go out. Whereas back home, you could be the only person in the pub. It's a really open city - you go out and you might never bump into an Irish person, it's all Australians, Zimbabweans, New Zealanders and so on, and its brilliant bumping into people from a wide variety of backgrounds; a lot more open than Scotland and people go out and socialize more. I think it is a kind of condensed version of London, it adds to your whole feeling of having diversity.

Dublin is a young city. Like, at home, none of the places are that big, Livingston, Edinburgh and even Glasgow, they're not that big really. If you went out every weekend with a group of friends you'd bump into the same people and you'd be in the same pubs and everyone would know everyone and there would be nothing exciting. I mean here you could go a million places and they'd be different people every weekend.

Moreover, Scots are selective about who they choose to be cosmopolitan with! Poorer migrants from Africa, China and Romania, for instance, are recognized as lying outwith the social circle, whilst Americans, Australians, New Zealanders and South Africans, and to a lesser extent other Europeans, represent core groups for mixing with.

It would be wrong, however, to think that Scottish people engage only with a kind of cosmopolitan veneer that sits afloat the nitty gritty of the rest of the city. Whilst Dublin does function as something of a superficial cosmopolitan boutique, it became clear from the focus groups that Scottish expatriates were feeding off a deeper vein of tolerance that had its roots in their acceptance into domestic Irish social networks. The Irish, it seemed, were going out of their way to make Scottish people in particular feel at home. The Irish hospitality to the Scots was variously attributed to the shared Celtic culture and political history of the two nations, the long history of migration between Scotland and Ireland, similar cultural attitudes, senses of humour, interest in language and social playfulness:

There are the connections between Ireland and Scotland, Celtic connections, so you are thought of as being one of them. We kind of have a shared culture, a similar sort of history so you can sort of blend in. I don't really think there is any such a thing as a Scottish community in Dublin. Apart from my boss, I haven't really met anyone else who is Scottish and all my friends are Irish. I think because the cultures are so similar we blend in.

It's probably xenophobic but there is certainly a strong link between the Scots and the Irish. The Scots and the Irish have a little bit of antagonism towards the English and it usually comes in handy to mark yourself out as Scottish rather than English in case anyone gets confused. Because of the proximity of Ireland to Scotland and their kind of shared history, it does seem to be a deeper relationship here. 
I've only ever been to one St Andrew's night and one Burns night and there was never anything organized. Maybe the Scottish community isn't so easily defined and you just naturally blend in and go with the flow. We are refugees here but we have good jobs and are not a threat to the Irish people. I've never had any sort of abuse from anybody coming up and asking me why I am here and taking jobs from an Irish person. I have known plenty of coloured people receiving abuse on the streets. I don't know, I suppose the Irish have lots of experience of Scottish people. If you asked $99 \%$ of them if they knew any Scottish people they would say yes. Maybe that's the problem, they do not know the other cultures. I think it's to do with the sense of humour too. The Irish and Scots can share a joke, and have a pint together, whereas an Irish and Nigerian probably cannot.

Arguably then, it is the importance of Dublin's open and tolerant attitude to the Scots, rather than the general and somewhat shallow cosmopolitan film, that sits on the surface of the city, that helps explain why Scots feel so at home. Florida is correct in arguing that cities that are open to diversity are a source of attraction to creative talent. In Dublin, however, a more potent source of social inclusion would seem to stem from the openness of the Irish to Scottish people in particular. In other words, Dublin appeals to the Scots first and foremost because of its openness to them, rather than its openness to all cultures more generally.

\section{From dialogue to synthesis: potential contributions of the creative class thesis to political economy frameworks}

Open season has now been declared on Florida and a number of scholarly critiques are emerging (for an extensive commentary on these critiques, see Milligan, 2003; Peck, 2005; Florida, 2005b: chapter 9). Critics from the right have reacted negatively to Florida's antipathy to traditional suburban and family lifestyles, attempts to link economic growth with alternative lifestyles, and reliance upon economic strategies which simply put 'lipstick on the gorilla' (Kotkin and Siegal, 2004; Malanga, 2004). Meanwhile, critics from the Left have attributed the popularity of Florida's ideas to the fact that they do little to disrupt neoliberal orthodoxies such as the need for inter-locality competition, league tables of attractiveness, place marketing, culture-led urban regeneration, and the inevitability of socio-economic difference (Kratke, 2004; Peck, 2005). Moreover, according to Peck (2005), Florida's policy programme actually serves to fortify neoliberal urbanism, by facilitating its capacity to cuddle up to a soft liberallooking veneer.

This article endorses the need to approach Florida's work critically. Instead of focusing upon its political and ideological foundations, however, it has taken the creative class thesis at face value and attempted to test its analytical prowess. Whilst reflections on the genealogy and spectacular diffusion of the thesis are important, there remains a more pressing need to test out whether it has any truth in actuality. This article has sought to assess the contributions which the creative class thesis might make to explanations of the rise of Tiger economies, which have hitherto been dominated by political economy perspectives. Its specific focus has been upon Florida's claim that cosmopolitanism and tolerance now constitute decisive assets in the global war to attract members of the creative class, who themselves are now vital brokers of urban and regional success. Using Scottish expatriates working in the Celtic Tiger as a test case, an effort has been made to gauge the extent to which the creative class thesis can be extended to account for the locational choices of skilled international migrants who settle in Tiger states.

A political economy reading might hold that skilled migrants leave Scotland and move to Dublin principally upon the basis of the uneven development of both economies. Ireland's flexible developmental state or developmental network state has delivered Tigerhood, economic growth has preceded migration, and differential labour market 
opportunities have emerged as the key driver. A Floridian reading in contrast might argue that Dublin's rise to prominence as a cool, youthful, European, and cosmopolitan cultural capital has played an equally significant role in drawing in Scottish expatriates, and that these migrants are just as much a cause as a consequence of the Celtic Tiger phenomenon. How far does the evidence go in supporting Florida's more cultural interpretation?

Using Florida's distinctions between work, everyday life and the life course, and community, the analyses presented above points to a mixed bag of results. The vast majority of Scottish expatriates move to Dublin primarily because of the city's outstanding career opportunities, but report a clear preference towards its more liberal workplace practices once in situ. Meanwhile, a smaller group of 'tumbleweeds' do approach Dublin as an ideal venue in which to 'morph' conventional lifestyle and lifecourse routines, but for the majority of participants everyday concerns and traditional life course pressures continue to impinge themselves to the extent that many do not see a long-term future in the city. Finally, Dublin does serve as a cosmopolitan vortex within which intense but shallow communities thrive, but shared historical experiences mean that Dublin is more open to Scots than to other nationalities. Whilst the creative class thesis does reveal crucial facets of the diasporic experience which would otherwise be overlooked, it contributes only a partial explanation of Scottish migration to Dublin.

In continuing to deploy oppositional thinking - culture versus economy - this article risks incurring the wrath of recent critics who claim that progress will only be made if the ontological unity of both categories is fully appreciated (Gregson et al., 2001). If the culture/economy schism is to be truly transcended and Florida's work is to do more than simply inform and enrich political economy readings of the rise of Tiger economies, then there will be a need to better understand the fact that the creativity exercised by talented people is as much a cultural practice as it is an economic and political one. There exists a dialectical relationship between the creativity of people in all walks of their lives, and their deployment of this creativity in the labour market and in the art of statecraft. Creativity, as a social and cultural resource, both constitutes and is constituted by the technological dynamism of the Irish economy and the flexibility of the Irish developmental state.

Using this kind of thinking, it will then be possible to introduce questions which thus far have been rarely even asked. Who, other than members of the creative class, would have the ingenuity and dexterity to rework the bureaucratic developmental states of Pacific Asia into the flexible developmental states which are now fermenting? To what extent do the value systems supported by the creative class now permeate the practices of the flexible developmental state? Are flexible developmental states run by members of the creative class? Can one detect the handicraft of creative talent in the architectures and practices of the flexible developmental state? Are these states functioning in the interests of creative talent to the detriment of other social groups? And, most fundamentally of all, what kinds of places are secreted out of the interactions between creative talent, technologically innovative economies, and flexible developmental states?

Mark Boyle (mark.boyle@strath.ac.uk), Department of Geography and Sociology, 50 Richmond St, University of Strathclyde, Glasgow G1 1XN, UK.

\section{References}

Abella, M.I. (2004) Labour migration in East Asian economies. Paper presented at Annual World Bank Conference on Development Economics, Europe, Brussels, 10-11 May 2004.
Alexander, W. (2003) Chasing the tartan Tiger: lessons from a Celtic cousin. The Smith Institute, London.

Allen, K. (1999) Immigration and the Celtic Tiger: a land of a thousand welcomes. In 
G. Dale and M. Cole (eds.), The European Union and migrant Labour, Berg, Oxford. Bartley, B. and K. Treadwell-Shine (2003) Competitive city: governance and the changing dynamics of urban regeneration in Dublin. In F. Moulaert, A. Rodriguez and E. Swngedouw (eds.), The globalised city: economic restructuring and social polarisation in European cities, Oxford University Press, Oxford.

Bayliss, D. (2004a) Ireland's creative development: local authority strategies for culture led development. Regional Studies 38, 817-31.

(2004b) Creative planning in Ireland: the role of culture-led development in Irish planning. European Planning Studies 12, 497-515.

Beaverstock, J.V. (2002) Transnational elites in global cities: British expatriates in Singapore. Geoforum 33, 525-38.

Boyle, M. and S. Motherwell (2005) Attracting and retaining talent: lessons for Scottish policy makers from the experiences of Scottish expatriates in Dublin. Scot Econ, Glasgow.

Bradley, J. (2005) Committing to growth in a small European economy. In D. Coyle, W. Alexander and B. Ashcroft (eds.), New wealth for old nations: Scotland's economic prospects, Princeton University Press, Princeton, NJ.

Brown, R. and M. Danson (2003) 'Going grey': demographic change and the changing labour market in Scotland. Local Economy 18, 291-305.

Central Bank and Financial Services Authority of Ireland (2005) Annual report 2005. Central Bank and Financial Services Authority of Ireland, Dublin.

Chang, T.C. (2000a) Renaissance revisited: Singapore as a global city for the arts. International Journal of Urban and Regional Research 24, 818-31.

_ (2000b) 'Singapore's little India: a tourist attraction as a contested landscape. Urban Studies 37, 343-66.

- and S.Y. Lim (2004) Geographical imaginations of new Asia-Singapore. Geografiska Annaler 86B, 165-85.

Clinch, P., F. Convery and B. Walsh (2002) After the Celtic Tiger: challenges ahead. The O'Brien Press, Dublin.

Coyle, D., W. Alexander and B. Ashcroft (eds.) (2005) New wealth for old nations: Scotland's economic prospects. Princeton University Press, Princeton, NJ.
Craig, C. (2003) The Scots crises of confidence. Big Thinking, Edinburgh.

Devine, T.M., C. Lee and G. Peden (2005) The transformation of Scotland: the economy since 1700. Edinburgh University Press, Edinburgh.

Eurostat (2004) EC economic data pocket book. Eurostat, Brussels.

Evans, P.B. (1995) Embedded autonomy. Princeton University Press, Princeton, NJ.

Fagan, G.H. (2002) Globalisation and culture: placing Ireland. Annals of the American Academy of Political and Social Science 581, 133-43.

FAS (2004) Irish labour market review, 2004. FAS, Dublin.

Ferreira, M.L. and P. Vanhoudt (2004) Catching the Celtic Tiger by its tail. European Journal of Education 39, 20935.

Findlay, A.M., F.L.N. Li, A.J. Jowett and R. Skeldon (1996) Skilled international migration and the global city: a study of expatriates in Hong Kong. Transactions of the Institute of British Geographers NS 21, 49-61.

—, H. Jones and G.M. Davidson (1998) Migration transition or migration transformation in the Asian dragon economies. International Journal of Urban and Regional Studies 22, 643-63.

Florida, R. (2002) The rise of the creative class - and how it's transforming work, leisure, community, and everyday life. Basic Books, New York.

- (2005a) The flight of the creative class. Harper Business, New York.

- (2005b) Cities and the creative class. Routledge, London.

- and I. Tinagli (2004) Europe in the creative age. Demos, London.

Fresh Talent Scotland (2004) New Scots: attracting fresh talent to meet the challenge of growth. Scottish Executive, Scotland.

Future Skills Scotland (2002) The Scottish labour market 2002. Scottish Enterprise, Glasgow.

Gibson, C. and N. Klocker (2004) Academic publishing as 'creative' industry, and recent discourses of 'creative economies': some critical reflections. Area 36, 42334.

Gregson, N., K. Simonsen and D. Vaiou (2001) Whose economy for whose culture? Moving beyond oppositional talk in European debate about culture and economy. Antipode 33, 616-46. 
Hardiman, N. (2005) Politics and markets in the Irish 'Celtic Tiger'. The Political Quarterly 76, 37-47

Harrison, R. and C. Mason (2003) The attraction and retention of high skilled labour. Scottish Enterprise, Glasgow.

House, J.D. and K. McGrath (2004) Innovative governance and development in the new Ireland: social partnership and the integrated approach. Governance: An International Journal of Policy, Administration, and Institutions 17, 29-58.

Hui, W.T. (1997) Regionalisation, economic restructuring and labour migration in Singapore. International Migration 35, 109-30.

Immigrant Council of Ireland (2003) Labour migration into Ireland. Immigrant Council of Ireland, Dublin.

Joshi, H.E. and R.E. Wright (2005) Starting life in Scotland. In D. Coyle, W. Alexander and B. Ashcroft (eds.), New wealth for old nations: Scotland's economic prospects, Princeton University Press, Princeton, NJ.

Kirby, P., L. Gibbons and M. Cronin (eds.) (2002) Reinventing Ireland: culture and the Celtic Tiger. Pluto Press, London

Kong, L. (2000) Introduction: culture, economy, policy: trends and developments. Geoforum 31, 385-90.

Kotkin, J. and F. Siegal (2004) Too much froth. Blueprint 6, 16-18.

Kratke, S. (2004) City of talents? Berlin's regional economy, socio-spatial fabric, and 'worst practice' urban governance.

International Journal of Urban and Regional Studies 28, 511-29.

Krugman, P. (2003) Eye of the Tiger. Sunday Business Herald 2, November.

Lennon, J.J. and A.V. Seaton (1998) Pathways to success: contrasting roles in public sector business development for tourism industries - a comparison of Glasgow and Dublin. International Journal of Public Sector Management 11, 139-53.

Li, F.L.N., A.M. Findlay and H. Jones (1998) A cultural economy perspective on service sector migration in the global city: the case of Hong Kong. International Migration 36, 131-57.

Low, L. (2002) The political economy of migrant worker policy in Singapore. Asia Pacific Business Review 8, 95-118. - (2005) Entrepreneurship development in Ireland and Singapore. Journal of theAsia Pacific Economy 10, 116-38.
Malanga, S. (2004) The curse of the creative class. City Journal Winter, 36-45.

McGlaughlin, G. and J. Salt (2002) Migration policies towards high skilled foreign workers. Home Office, London.

McPherson, A.H. and W.K. Roche (1997) Peripheral location equals localised labour? Multinationals and the internationalisation of training and development in Ireland. The International Journal of Human Resource Management 8, 369-84.

McSharry, R. and P. White (2000) The making of the Celtic Tiger: the inside story of Ireland's boom economy. Mercier Press, Dublin.

Miles, S. and R. Paddison (2005) Introduction: the rise and rise of culture led urban regeneration. Urban Studies 42, 833-9.

Milligan, M.J. (2003) The individual and city life: a commentary on Richard Florida's 'cities and the creative class'. City and Community 2, 21-6.

Millington, S. and C. Young (2003) Producing the cosmopolitan city. Cosmopolitanism and urban regeneration in Dublin, Republic of Ireland. Paper presented at the Association of American Geographers Conference, New Orleans, March.

O'Hearn, D. (1998) Inside the Celtic Tiger: the Celtic Tiger and the Asian model. Pluto Press, London.

- (2000) Globalisation, 'new tigers' and the end of the developmental state? The case of the Celtic Tiger. Politics and Society 28, 6792.

(2001) The Atlantic economy: Britain, the US and Ireland. Manchester University Press, Manchester.

O'Riain, S. (2000) The flexible developmental state: globalisation, information technology and the Celtic Tiger. Politics and Society 28, 157-93.

- (2004) The politics of high technology growth: developmental network states in the global economy. Cambridge University Press, Cambridge.

Pang, E.F. (1994) An eclectic approach to turning points in migration. Asian and Pacific Migration Journal 3, 81-92.

Peck, J. (2005) Struggling with the creative class. International Journal of Urban and Regional Research 29, 740-70.

Pratt, A. (2004) The cultural economy: a call for spatialised production of culture perspectives. International Journal of Cultural Studies 7, 117-28. 
Randall, J. (2002) Scotland's population: current trends and future prospects. GROS, Edinburgh.

Shields, R. (1999) Culture and the economy of cities. European Urban and Regional Studies 6, 303-11.

Simonsen, K. (1999) Overcoming the economy/culture division. European Urban and Regional Studies 6, 312-14.

- (2001) Space, culture and economy - a question of practice. Geografiska Annaler $B$ $83,41-52$.

Sparke, M., J.D. Sidaway, T. Bunnell and C.G. Warr (2004) Triangulating the borderless world: geographies of power in the Indonesia-Malaysia-growth triangle. Transactions of the Institute of British Geographers NS 29, 485-98.

Taylor, G. (2000) Hailing with an invisible hand: a 'cosy' political dispute amid the rise of neoliberal politics in modern Ireland. Government and Opposition 37, 501-23.
Valarasan-Toomey, M. (1998) The Celtic Tiger: from the outside looking in. Blackhall Publishers, Dublin.

Wee, C.J.W.L. (2001) Mediating 'progress': the national narrative of economic development and liberalism in Singapore. Journal of Transnational and Cross-cultural Studies 9, 223-42.

Wickham, J. and G.W. Boucher (2004) Training cubs for the Celtic Tiger: the volume production of technical graduates in the Irish educational system. Journal of Education and Work 17, 377-85.

Yeoh, B.S.A. (2005) The global cultural city? Spatial imagineering and politics in the (multi)cultural marketplaces of South-East Asia. Urban Studies 42, 945-58. and T.C. Chang (2001) Globalising Singapore: debating transnational flows in the city. Urban Studies 38, 1025-44.

\section{Résumé}

L'article évalue en quoi la thèse décisive de Richard Florida sur la 'classe créative' pourrait contribuer aux tentatives actuelles de ré-intégrer la 'culture' dans les explications économico-politiques de la montée des économies du Tigre. Il réfléchit à l'intérêt de revenir sur le rôle des migrants qualifiés dans les États du Tigre, ainsi que sur les facteurs qui les y attirent a priori. A partir d'analyses d'une série de groupes de discussion impliquant des expatriés écossais qui travaillent à Dublin, l'article s'efforce en particulier d'apprécier la portée de la thèse de la classe créative pour justifier les préférences d'implantation des migrants très compétents. Si le travail de Florida a indubitablement clarifié des facettes de l'existence des expatriés qui, sinon, ne seraient pas si évidentes, il convient de remettre en cause son aptitude à expliquer les rapports entre technologie, talent et tolérance chez le Tigre celte. De plus, bien que l'économie politique et les interprétations de Florida fassent davantage que de se renseigner mutuellement, il faudra déterminer plus nettement les manières complexes selon lesquelles des États en développement recoupent des flux de compétences et des programmes culturels cosmopolites. 